\title{
IN VITRO INTERACTIONS BETWEEN LACTIC ACID SOLUTION AND ART GLASS-IONOMER CEMENTS
}

\author{
Linda WANG ${ }^{1}$, Daniela Francisca Gigo CEFALY ${ }^{2}$, Janaína Lima dos SANTOS ${ }^{3}$, Jean Rodrigo dos SANTOS ${ }^{3}$ \\ José Roberto Pereira LAURIS ${ }^{4}$, Rafael Francisco Lia MONDELLI ${ }^{5}$, Maria Teresa ATTA ${ }^{5}$
}

\author{
1- DDS, MSc, PhD, Assistant Professor, Department of Operative Dentistry, Endodontics and Dental Materials, Bauru School of Dentistry, University \\ of São Paulo, Bauru, SP, Brazil. \\ 2- DDS, MSc, PhD, Assistant Professor, Department of Operative Dentistry, University of North of Paraná, Londrina, PR, Brazil. \\ 3- Undergraduate student, University of North of Paraná, Londrina, PR, Brazil. \\ 4- PhD, Associate Professor, Department of Pediatric Dentistry, Orthodontics and Community Health, Bauru School of Dentistry, University of São \\ Paulo, Bauru, SP, Brazil. \\ 5- DDS, MSc, PhD, Associate Professor, Department of Operative Dentistry, Endodontics and Dental Materials, Bauru School of Dentistry, University \\ of São Paulo, Bauru, SP, Brazil.
}

Corresponding address: Profa. Dra. Linda Wang - Departamento de Dentística, Endodontia e Materiais Dentários, Faculdade de Odontologia de Bauru, Universidade de São Paulo - Alameda Octávio Pinheiro Brisolla, 9-75 - 17012-901, Bauru, SP, Brazil. - Phone: +55-14-3235-8325 - FAX: +5514-3235-8323 - e-mail: wang.linda@usp.br

Received: April 28, 2008 - Modification: November 11, 2008 - Accepted: November 13, 2008

\begin{abstract}
$O$

bjectives: Production of acids such as lactic acid contributes to establish a cariogenic environment that leads to dental substrate demineralization. Fluoride plays an important role in this case and, as fluoride-releasing materials, glass-ionomer cements are expected to contribute to minimize deleterious reactions. This study evaluated interactions of glass-ionomer cements used in atraumatic restorative treatment (ART-GICs) with an aqueous lactic acid solution, testing the null hypotheses that no changes occur in the $\mathrm{pH}$ of the solution or on the surface roughness and mass of the ART-GICs when exposed to lactic acid solution over a 6-week period. Material and Methods: Ketac Molar, Fuji IX, Vitro Molar and Magic Glass were tested, and compared to Filtek Z250 and Ketac Fil Plus as control groups. Six specimens of each material were made according to manufacturers' instructions. The $\mathrm{pH}$ of the solution and roughness and mass changes of each specimen were determined over 6 weeks. Each specimen was individually stored in $2 \mathrm{~mL}$ of $0.02 \mathrm{M}$ lactic acid solution for 1 week, renewing the solution every week. $\mathrm{pH}$ of solution and mass of the specimens were monitored weekly, and surface roughness of the specimens was assessed before and at the end of the 6-week acid challenge. $\mathrm{pH}$ and mass data were analyzed statistically by repeated measures using one-way ANOVA and Tukey's post-hoc tests for each material. Paired t-tests were used for roughness analysis. Tukey's post-hoc tests were applied to verify differences of final roughness among the materials. Significance level was set at 5\%. Results: The null hypotheses were partially rejected. All materials were able to increase the $\mathrm{pH}$ of the lactic acid solution and presented rougher surfaces after immersion, while mass change was minimal and generally not statistically significant. Conclusions: These findings can be helpful to predict the performance of these materials under clinical conditions. A protective action against the carious process with significant surface damage due to erosion may be expected.
\end{abstract}

Key words: Glass-ionomer cements. Atraumatic restorative treatment. Lactic acid. $\mathrm{pH}$

\section{INTRODUCTION}

Atraumatic restorative treatment (ART) is a dental approach based on the removal of carious tissue with hand instruments followed by placement of an adhesive restoration ${ }^{2,7,24,29}$. It is recommended by the World Health Organization (WHO), mainly in communities with poor financial resources and for people who have physical disabilities or are fearful ${ }^{2,7,24,29}$. As ART is usually applied to unprivileged people, poor oral hygiene is common, with consequent unbalance of the demineralizationremineralization cycles, is common.

Glass-ionomer cement (GIC) is usually the adhesive material of choice to treat high-caries risk patients, and it is feasible to assume that the GIC will be in direct contact with acid substances ${ }^{9,10,30}$. Variation in acid profile and concentration may relate to caries progression in hard dental tissues ${ }^{12,13}$. When sugar is available in the oral environment, microorganisms produce organic acids such as lactate and acetate ${ }^{23}$. Another relevant factor involved in caries progression is related to the low $\mathrm{pH}$ generated from carbohydrate metabolism that selects cariogenic species ${ }^{3,23}$. Hojo, et al. ${ }^{12}$ (1994) observed that a low $\mathrm{pH}$ environment characterizes this condition with a lactate dominant acid profile in active lesions. Thus, the interaction between lactic acid and restorative materials should also be 
considered.

ART requires a material with improved mechanical properties. Since conventional GICs are not indicated for restoring stress-bearing contact areas ${ }^{5,14,22,25,26,30}$, some types of GICs have been specifically formulated for ART restorations. In vitro studies have compared the performance of conventional

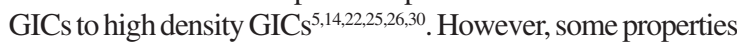
of ART-GICs still need to be further investigated. Previous studies have stated the negative influence of acids on restorative materials ${ }^{11,19,20,23}$. Resistance to biodegradation is a highly desirable property of dental materials to allow for satisfactory clinical performance.

The aim of this study was to evaluate interactions of ARTGICs with an aqueous lactic acid solution. The null hypotheses tested are that no significant changes occur in the $\mathrm{pH}$ of the solution or on the surface roughness and mass of the ARTGICs when the materials are exposed to an aqueous lactic acid storage solution over a 6-week period.

\section{MATERIAL AND METHODS}

The materials under investigation with their compositions and manufacturers are presented in Figure 1.

Six specimens of each material $(6 \mathrm{~mm}$ diameter $\mathrm{x} 3 \mathrm{~mm}$ in height) were prepared. Conventional (positive control) and ART-GICs were weighed according to powder-to-liquid mixing ratio indicated by the manufacturers. Materials were inserted into a previously lubricated cylindrical polytetrafluoroethylene molds with a Centrix syringe (Centrix, Shelton, CT, USA) between two polyester strips (TDV Dental, Pomerode, SC, Brazil) and pressed with glass slabs under a constant load of $500 \mathrm{~g}$. After $30 \mathrm{~min}$, the specimens were removed from the molds and excess was cut off with a \#12 Bard-Parker scalpel blade. Filtek Z250 specimens (negative control) were inserted into the molds in a single increment, which was light-cured for 20 s on both sides using a halogen lamp (Optilight Plus; Gnatus, Ribeirão Preto, SP, Brazil) with irradiance of $400 \mathrm{~mW} / \mathrm{cm}^{2}$, as measured with a curing radiometer (Model 100P/N-150503; Demetron Research Corp., Danbury, CT, USA).

Immediately after preparation, mass and surface roughness of the specimens were determined. The mass was assessed in an analytical balance (Bel Engineering SRL, Mark 205A, Monza, MI, Italy) accurate to $0.0001 \mathrm{~g}$. Surface roughness was analyzed by a Hommel Tester T 1000 (Hommelwerke GmbH, Schwenningen, Germany) accurate to $0.01 \mathrm{~mm}$ and was expressed in $\mathrm{mm}$ as a $R a$ value. To record roughness measurements of the surfaces a device containing a diamond needle (Hommelwerke $\mathrm{GmbH}$ ) was used. The average of three randomized readings was established as the baseline roughness

\begin{tabular}{|c|c|c|c|}
\hline Material & Type & Composition & Manufacturer \\
\hline Filtek Z250 & Composite resin & $\begin{array}{l}\text { Organic matrix. BIS-GMA, UEDMA, BIS- } \\
\text { EMA. Inorganic filler: } 60 \% \text { by volume } \\
\text { zirconia/silica }\end{array}$ & $\begin{array}{c}\text { 3M/ESPE, St. Paul, } \\
\text { MN, USA }\end{array}$ \\
\hline Ketac Fil Plus & Conventional GIC & $\begin{array}{l}\text { Powder. Calcium aluminum lanthanum } \\
\text { fluorosilicate glass, strontium. } \\
\text { Liquid: Water, acrylic and maleic acids } \\
\text { copolymer, tartaric acid and benzoic acid }\end{array}$ & $\begin{array}{c}\text { 3M/ESPE, St. Paul, } \\
\text { MN, USA }\end{array}$ \\
\hline Ketac Molar & ART GIC & $\begin{array}{l}\text { Powder. Calcium aluminum lanthanum } \\
\text { fluorosilicate glass, copolymer, pigments } \\
\text { Liquid: Acrylic acid, maleic acid copolymer, } \\
\text { tartaric acid, benzoic acid }\end{array}$ & $\begin{array}{c}\text { 3M/ESPE, St. Paul, } \\
\text { MN, USA }\end{array}$ \\
\hline Fuji IX & ART GIC & $\begin{array}{c}\text { Powder. Aluminosilicate glass, } \\
\text { polyacrylic acid } \\
\text { Liquid: Polyacrylic acid, polybasic acid }\end{array}$ & $\begin{array}{l}\text { GC Corp., Tokyo, } \\
\text { Japan }\end{array}$ \\
\hline Vitro Molar & ART GIC & $\begin{array}{c}\text { Powder: barium calcium fluoro } \\
\text { aluminosilicate glass } \\
\text { Liquid: Polyacrylic acid and tartaric acid }\end{array}$ & $\begin{array}{c}\text { DFL, Rio de Janeiro, } \\
\text { RJ, Brasil }\end{array}$ \\
\hline Magic Glass & ART GIC & $\begin{array}{c}\text { Powder: Aluminosilicate glass } \\
\text { Liquid: Polycarboxylic acid }\end{array}$ & $\begin{array}{l}\text { Vigodent, Rio de } \\
\text { Janeiro, RJ, Brasil }\end{array}$ \\
\hline
\end{tabular}

$\mathrm{ART}=$ atraumatic restorative treatment; GIC: glass-ionomer cement.

FIGURE 1- Materials used in the study 
value. $R a$ range was previously adjusted at 0.01 to $0.8 \mathrm{~mm}$ at a cut-off of $0.25 \mathrm{~mm}$. Readings were obtained from $1.5 \mathrm{~mm}$ long measurements.

A $0.02 \mathrm{M}$ aqueous lactic acid solution was prepared $18 \mathrm{~h}$ before use to allow hydrolysis of lactone to occur, according to ISO standard $9917^{15}$. This reagent was always freshly prepared for each set of tests. The specimens were individually stored for 6 weeks in glass vials containing $2 \mathrm{~mL}$ of the solution, which was weekly renewed. A vial containing lactic acid aqueous solution at $\mathrm{pH} 2.7 \pm 0.02$ with no specimen was used to monitor the $\mathrm{pH}$ of the solution over the week. The vials were maintained at $23 \pm 1^{\circ} \mathrm{C}$ without agitation. After 1 week, the $\mathrm{pH}$ of solution in each vial was measured with a pHmeter (Tecnal $\mathrm{pH}$ meter Tec-2, Piracicaba, SP, Brazil). Mass change of each specimen was also recorded and the specimens were transferred to individual vials with fresh solution. After the end of the 6-week period, new surface roughness readings were performed.

The assumptions of equality of variances and normal distribution of errors were checked for the tested response variables. Since the assumptions were satisfied, data were subjected to one-way ANOVA using matched repeated measures and Tukey's post-hoc tests for $\mathrm{pH}$ and mass analysis. Paired t-tests were used for roughness analysis. Tukey's posthoc tests were applied to verify differences of final roughness among the materials $(\mathrm{p}<0.05)$.

\section{RESULTS}

The $\mathrm{pH}$ increasing ability was material- and timedependent as was the interaction between these variables $(\mathrm{p}<0.05)$. All materials increased the $\mathrm{pH}$ of the lactic acid

TABLE 1- Means (standard deviations) of $\mathrm{pH}$ values of lactic acid solutions over 6 weeks storage

\begin{tabular}{llllllll}
\hline Material & Initial & 1 week & 2 week & $\mathbf{3}$ week & $\mathbf{4}$ week & $\mathbf{5}$ week & $\mathbf{6}$ week \\
\hline Filtek Z250 & $2.7^{\mathrm{a}}(0.00)$ & $2.83^{\mathrm{d}}(0.05)$ & $2.77^{\mathrm{c}}(0.03)$ & $2.73^{\mathrm{ab}}(0.01)$ & $2.78^{\mathrm{c}}(0.01)$ & $2.77^{\mathrm{c}}(0.00)$ & $2.75^{\mathrm{bc}}(0.02)$ \\
Ketac Fil Plus & $2.7^{\mathrm{a}}(0.00)$ & $4.28^{\mathrm{e}}(0.05)$ & $3.74^{\mathrm{d}}(0.03)$ & $3.61^{\mathrm{d}}(0.02)$ & $3.59^{\mathrm{c}}(0.01)$ & $3.53^{\mathrm{b}}(0.02)$ & $3.49^{\mathrm{b}}(0.03)$ \\
Ketac Molar $^{\mathrm{a}}$ & $2.7^{\mathrm{a}}(0.00)$ & $3.83^{\mathrm{e}}(0.05)$ & $3.50^{\mathrm{d}}(0.02)$ & $3.47^{\mathrm{cd}}(0.02)$ & $3.48^{\mathrm{cd}}(0.02)$ & $3.44^{\mathrm{bc}}(0.03)$ & $3.41^{\mathrm{b}}(0.01)$ \\
Fuji IX & $2.7^{\mathrm{a}}(0.00)$ & $4.08^{\mathrm{e}}(0.07)$ & $3.59^{\mathrm{d}}(0.03)$ & $3.56^{\mathrm{cd}}(0.03)$ & $3.55^{\mathrm{cd}}(0.04)$ & $3.50^{\mathrm{bc}}(0.03)$ & $3.45^{\mathrm{b}}(0.02)$ \\
Vitro Molar & $2.7^{\mathrm{a}}(0.00)$ & $4.85^{\mathrm{c}}(0.34)$ & $4.22^{\mathrm{c}}(0.16)$ & $4.12^{\mathrm{c}}(0.10)$ & $4.06^{\mathrm{c}}(0.06)$ & $4.06^{\mathrm{c}}(0.04)$ & $4.044^{\mathrm{b}}(0.05)$ \\
Magic Glass & $2.7^{\mathrm{a}}(0.00)$ & $4.82^{\mathrm{e}}(0.12)$ & $4.78^{\mathrm{e}}(0.13)$ & $4.72^{\mathrm{de}}(0.31)$ & $4.56^{\mathrm{cd}}(0.20)$ & $4.44^{\mathrm{c}}(0.22)$ & $4.21^{\mathrm{b}}(0.12)$ \\
\hline
\end{tabular}

Values are expressed as mean (standard deviation). Same letter indicates no statistically significant difference in rows.

TABLE 2- Mass of the control materials and ART-GICs exposed to the aqueous lactic acid storage solution over a 6-week period

\begin{tabular}{|c|c|c|c|c|c|c|c|c|}
\hline Material & Initial & 1 week & 2 week & 3 week & 4 week & 5 week & 6 week & $p$ value \\
\hline Filtek & $0.2086^{a}$ & $0.2130^{a}$ & $0.2132^{a}$ & $0.2133^{a}$ & $0.2134^{a}$ & $0.2134^{a}$ & $0.2134^{a}$ & $p>0.05$ \\
\hline Z250 & $(0.0009)$ & $(0.0124)$ & $(0.0124)$ & $(0.0124)$ & $(0.0124)$ & $(0.0123)$ & $(0.0122)$ & \\
\hline Ketac Fil & $0.2422^{\mathrm{a}}$ & $0.2326^{a}$ & $0.2322^{\mathrm{a}}$ & $0.2317^{a}$ & $0.2311^{a}$ & $0.2303^{a}$ & $0.2298^{a}$ & $p>0.05$ \\
\hline Plus & $(0.0141)$ & $(0.0187)$ & $(0.0187)$ & $(0.0187)$ & $(0.0187)$ & $(0.0189)$ & $(0.0188)$ & \\
\hline Ketac & $0.2343^{a}$ & $0.2398^{a}$ & $0.2431^{a}$ & $0.2433^{a}$ & $0.2427^{a}$ & $0.2427^{a}$ & $0.2426^{a}$ & $p>0.05$ \\
\hline Molar & $(0.0118)$ & $(0.0160)$ & $(0.0147)$ & $(0.0147)$ & $(0.0144)$ & $(0.0143)$ & $(0.0142)$ & \\
\hline \multirow[t]{2}{*}{ Fuji IX } & $0.1983^{a}$ & $0.2341^{b}$ & $0.2339^{b}$ & $0.2337^{b}$ & $0.2334^{b}$ & $0.2327^{b}$ & $0.2323^{b}$ & $p<0.05$ \\
\hline & $(0.0141)$ & $(0.0121)$ & $(0.0121)$ & $(0.0120)$ & $(0.0121)$ & $(0.0123)$ & $(0.0122)$ & \\
\hline Vitro & $0.2117^{a b}$ & $0.2155^{c}$ & $0.2149 \mathrm{bc}$ & $0.2159^{c}$ & $0.2112^{a}$ & $0.2135 a b c$ & $0.2131 \mathrm{abc}$ & $p>0.05$ \\
\hline Molar & $(0.0185)$ & $(0.0187)$ & $(0.0189)$ & $(0.0187)$ & $(0.0179)$ & $(0.0187)$ & $(0.0189)$ & \\
\hline Magic & $0.2328^{a}$ & $0.2011^{b}$ & $0.1993^{b}$ & $0.1978^{b}$ & $0.1960^{b}$ & $0.1941^{b}$ & $0.1924^{b}$ & $p<0.05$ \\
\hline Glass & $(0.0184)$ & $(0.0131)$ & $(0.0134)$ & $(0.0134)$ & $(0.0134)$ & $(0.0137)$ & (0.0133) & \\
\hline
\end{tabular}

$\mathrm{ART}$ = atraumatic restorative treatment; GIC: glass-ionomer cement. Values are expressed as mean (standard deviation). Same letter indicates no statistically significant difference in the same row. 
TABLE 3- Mean initial and final surface roughness $(R a)$ of the control materials and ART-GICs exposed to the aqueous lactic acid storage solution over a 6-week period

\begin{tabular}{lccc}
\hline Material & Initial roughness $(\mu \mathrm{m})$ & Final roughness $(\mu \mathrm{m})$ & Tukey's tests \\
\hline Filtek Z250 & $0.25^{\mathrm{a}}(0.12)$ & $0.62^{\mathrm{b}}(0.30)$ & $\mathrm{A}$ \\
Ketac Fil Plus & $0.54^{\mathrm{a}}(0.13)$ & $1.19^{\mathrm{b}}(0.42)$ & $\mathrm{B}, \mathrm{C}$ \\
Ketac Molar & $0.47^{\mathrm{a}}(0.22)$ & $0.83^{\mathrm{b}}(0.38)$ & $\mathrm{A}, \mathrm{B}$ \\
Fuji IX & $0.63^{\mathrm{a}}(0.16)$ & $0.95^{\mathrm{b}}(0.28)$ & $\mathrm{A}, \mathrm{B}, \mathrm{C}$ \\
Vitro Molar & $0.82^{\mathrm{a}}(0.29)$ & $1.37^{\mathrm{b}}(0.28)$ & $\mathrm{C}$ \\
Magic Glass & $0.46^{\mathrm{a}}(0.15)$ & $1.26^{\mathrm{b}}(0.12)$ & $\mathrm{B}, \mathrm{C}$ \\
\hline
\end{tabular}

ART = atraumatic restorative treatment; GIC: glass-ionomer cement. The values are expressed as mean (standard deviation). Same superscript letter indicates no statistically significant difference in the same row by paired t-test. Same uppercase letter indicates no statistically significant difference for final roughness among the materials.

storage solution at all evaluation periods $(\mathrm{p}<0.01)$. The $\mathrm{pH}$ changes of the aqueous lactic acid solution recorded over a 6 -week period of storage of the materials are presented in Table 1. Greater increase in lactic acid $\mathrm{pH}$ was observed in the first week for all materials followed by a clear decrease over time. However, for all materials, the final $\mathrm{pH}$ of the acid solution was always higher than the initial $\mathrm{pH}(\mathrm{p}<0.05)$. All GICs showed more increasing $\mathrm{pH}$ potential than the composite resin.

Mass change data (Table 2) showed statistical significance for material and material versus time interaction $(\mathrm{p}<0.05)$. Fuji IX showed mass gain in the first week, which was stabilized from the second week. Conversely, Magic Glass lost mass in the first week, stabilizing from the second week. Vitro Molar showed a discrete gain of mass in the first week and mass loss in the fourth week. Ketac Molar, Ketac Fil Plus and Filtek Z250 showed insignificant changes in the evaluated period. There were no statistically significant differences among Fuji IX, Magic Glass and Ketac Fil Plus.

For surface roughness analysis (Table 3), all materials were rougher after 6 weeks $(\mathrm{p}<0.05)$. No statistically significant difference $(\mathrm{p}>0.05)$ was observed for interaction between material and time. Filtek Z250 and Ketac Molar presented the least alterations while Vitro Molar showed the greatest alterations on surface roughness. There were no statistically significance differences ( $>>0.05)$ among Fuji IX, Magic Glass and Ketac Fil Plus.

\section{DISCUSSION}

The anticariogenic capacity is a relevant property of GICs and it is thus expected that the interaction of these materials with an acidic environment will lead to $\mathrm{pH}$ increase ${ }^{10,17-19}$ Under the present experimental conditions, all tested GICs were able to increase the initial $\mathrm{pH}$ of the acid lactic solution, though a progressive decline of this ability occurred for all materials over time. These results are in accordance with those of Nicholson, et al. ${ }^{19}$, who subjected polyacid-modified composite resins to similar experimental conditions and also verified their ability to neutralize acidic solution. The profile in the same period of evaluation also indicated a decline of this property over time. Nomoto and $\mathrm{McCabe}^{21}$ verified that the initial $\mathrm{pH}$ of the tested solution (2.74) increased almost 1 unit in 7 days. Nicholson, et al. ${ }^{17}$ investigated the rate of change of the $\mathrm{pH}$ of lactic acid exposed to some ART-GICs and their results corroborate the findings of the present study.

The $\mathrm{pH}$ increase of acid storage solution is attributed to the acid-basic setting reaction of dental cements with salt formation. A possible explanation is that lactic acid reacts directly with basic glass filler to form calcium and aluminum lactate salts. Lactic acid is a stronger organic acid and it reacts with these salts forming lactate dominant salts ${ }^{20,21}$.

Despite the benefits of increasing the $\mathrm{pH}$ of acid environments as an important mechanism of caries protection for GICs, these materials can be damaged in this interaction. Different methodologies, such as surface roughness ${ }^{28}$, microhardness ${ }^{4,11}$, mass change ${ }^{17,20}$ and scanning electron microscopy ${ }^{8}$, have been applied to investigate the influence of acidic conditions on different restorative materials. In the present study, mass and surface roughness analyses were performed. The results showed that the increase of the $\mathrm{pH}$ of the acidic solution led to minimal material loss, which could be related to an erosive process $^{1,18,20,21}$. Generally, mass change was not statistically significant, which does not mean that no phenomena occurred. It is more likely that the expected mass gain by water sorption was similar to the loss of material eroded from the surface ${ }^{1}$. Only Fuji IX revealed a significant initial mass gain, while Magic Glass lost mass at the same period. This difference can be attributed to differences in the materials' formulations. Regardless of their performance, the degradation of these materials can involve loss of sodium, fluoride ions and silica or matrix biodegradation ${ }^{18}$. On the other hand, mass gain can also result from the formation of insoluble glass-lactate cement.

It is important to state that the low $\mathrm{pH}$ of acidic solutions optimizes surface damage to the specimens caused by water content, since previous studies showed that an aqueous environment has a significant effect on the surfaces of the 
materials ${ }^{11}$. Similar results have been reported by Turssi, et al. ${ }^{28}$ No specific qualitative analysis of the surfaces was performed in the present study, but all GIC specimens presented a chalky surface at the end of the experimental period, which may be suggestive of an erosive process ${ }^{18}$. Other methodologies can be used to investigate the performance of dental restorative materials under erosive conditions, such as the method of dripping/spraying acid solution and measuring volume rather than mass ${ }^{21}$.

In order to confirm the occurrence of any surface alteration, this study proposed a quantitative investigation using a roughness tester. An increase of surface roughness was evident for all tested materials. Nomoto and $\mathrm{McCabe}^{21}$ also verified the capacity of acid to erode GIC surfaces. Turssi, et al. ${ }^{28}$ investigated the role of the immersion solution on the roughness of resin-based restorative materials and concluded that micromorphological changes occurred in an acid-challenging situation. The concern about increased surface roughness is that rough surfaces can predispose restorations to staining, plaque and food accumulation, and gingival irritation ${ }^{6,16,27}$.

The relationship among factors related to caries onset and progression is controversial because of several events are involved. However, it is known that a low $\mathrm{pH}$ is favorable to establish a condition that facilitates demineralization of hard dental tissue ${ }^{11,19,23}$. In the present study, an increased $\mathrm{pH}$ of acidic storage solution was observed over time after contact with the tested materials. This performance is an important predictive that GICs present a real potential to arrest caries. In the oral environment, however, the proportion between dental material and acidic fluid is different. Yet, although other factors should be associated to permit a correct interpretation, an enhanced performance of all materials is expected clinically.

\section{CONCLUSION}

According to the proposed methodology and based on the obtained results, the null hypotheses tested in this study were partially rejected. All GICs increased the $\mathrm{pH}$ of the lactic acid solution, though this ability declined over time. All materials presented higher surface roughness at the end of the lactic acid challenge. Minimal mass change occurred throughout the experiment. These findings can be helpful to predict the performance of these materials under clinical conditions. A protective action against the carious process with significant surface damage due to erosion may be expected.

\section{ACKNOWLEDGEMENTS}

The authors thank Thelma Lopes da Silva and Veralúcia dos Santos for laboratory assistance. We also thank 3M/ ESPE Dental Products, DFL and, Vigodent for material support.

\section{REFERENCES}

1- Bapna MS, Mueller HJ. Relative solubilities of hybrid ionomers and compomers by acid impingement. J Oral Rehabil. 1999;26(10):786-90.

2- Barata TJE, Bresciani E, Mattos MCR, Lauris JRP, Ericson D, Navarro MFL. Comparison of two minimally invasive methods on the longevity of glass ionomer cement restorations: short-term results of a pilot study. J Appl Oral Sci. 2008;16(2):155-60.

3- Bradshaw DJ, Marsh PD. Analysis of pH-driven disruption of oral microbial communities in vitro. Caries Res. 1998;32(6):456-62.

4- Chadwick RG, McCabe JF, Walls AWG, Storer R. The effect of storage media upon the surface microhardness and abrasion resistance of three composites. Dent Mater. 1990;6(2):123-8.

5- Ewoldsen N, Covey D, Lavin M. The physical and adhesive properties of dental cements used for atraumatic restorative treatment. Spec Care Dentist. 1997;17(1):19-24.

6- Forss H, Jokinen J, Spets-Happonen S, Seppä L, Luoma H. Fluoride and mutans streptococci in plaque grown on glass ionomer and composite. Caries Res. 1991;25(6):454-8.

7- Frencken JE, Songpaisan Y, Phantumvanit P, Pilot T. An atraumatic restorative treatment (ART) technique: evaluation after one year. Int Dent J. 1994;44(5):460-4.

8- Gao F, Matsuya S, Ohta M, Zhang J. Erosion process of light-cured and conventional glass ionomer cements in citrate buffer solution. Dent Mater J. 1997;16(2):170-9.

9- Gao W, Smales RJ, Gale MS. Fluoride release/uptake from newer glassionomer cements used with the ART approach. Am J Dent. 2000;13(4):201-4.

10- Garcez RMV, Buzalaf MAR, Araújo PA. Fluoride release of six restorative materials in water and $\mathrm{pH}$-cycling solutions. J Appl Oral Sci. 2008;15(5):406-11.

11- Geurtsen W, Leyhausen G, Garcia-Godoy F. Effect of storage media on the fluoride release and surface microhardness of four polyacidmodified composite resins ("compomers"). Dent Mater. 1999;15(3):196201.

12- Hojo S, Komatsu M, Okuda R, Takahashi N, Yamada T. Acid profiles and $\mathrm{pH}$ of carious dentine in active and arrested caries. J Dent Res. 1994;73(12):1853-7.

13- Hojo S, Takahashi N, Yamada T. Acid profiles in carious dentin. J Dent Res. 1991;70(3):182-6.

14- Hosoya Y, García-Godoy F. Bonding mechanism of Ketac-Molar Aplicap and Fuji IX GP to enamel and dentin. Am J Dent. 1998;11(5):2359.

15- International Organization for Standardization. ISO 9917. Specification for dental water-based dental cements. Geneva: The Organization; 2003.

16- Lindquist B, Emilson CG. Distribution and prevalence of mutans streptococci in the human dentition. J Dent Res. 1990;69(5):1160-6.

17- Nicholson JW, Aggarwal A, Czarnecka B, Limanowska-Shaw H. The rate of change of $\mathrm{pH}$ of lactic acid exposed to glass-ionomer dental cements. Biomaterials. 2000;21(19):1989-93.

18- Nicholson JW, Czarnecka B, Limanowska-Shaw H. A preliminary study of the effect of glass-ionomer and related dental cements on the $\mathrm{pH}$ of lactic acid storage solutions. Biomaterials. 1999;20(2):155-8. 
19- Nicholson JW, Czarnecka B, Limanowska-Shaw H. The interaction of glass-ionomer cements containing vinylphosphonic acid with water and aqueous lactic acid. J Oral Rehabil. 2003;30(2):160-4.

20- Nicholson JW, Millar BJ, Czarnecka B, Limanowska-Shaw H. Storage of polyacid-modified resin composites ("compomers") in lactic acid solution. Dent Mater. 1999;15(6):413-6.

21- Nomoto R, McCabe JF. A simple acid erosion test for dental waterbased cements. Dent Mater. 2001;17(1):53-9.

22- Platt JA, Rhodes B. Microleakage of high-strength glass ionomer: resin composite restorations in minimally invasive treatment. J Indiana Dent Assoc. 2002;80(4):20-2.

23- Prakki A, Cilli R, Mondelli RFL, Kalachandra S, Pereira JC. Influence of $\mathrm{pH}$ environment on polymer based dental materials properties. J Dent. 2005:33(2):91-8

24- Rahimtoola S, Amerongen E van, Maher R, Groen H. Pain related to different ways of minimal intervention in the treatment of small caries lesions. ASDC J Dent Child. 2000;67(2):123-7.

25- Smales RJ, Gao W, Ho FT. In vitro evaluation of sealing pits and fissures with newer glass-ionomer cements developed for the ART technique. J Clin Pediatr Dent. 1997;21(4):321-3.

26- Smales RJ, Gao W. In vitro caries inhibition at the enamel margins of glass ionomer restoratives developed for the ART approach. J Dent 2000;28(4):249-56.

27- Steinberg D, Eyal S. Early formation of Streptococcus sobrinus biofilm on various dental restorative materials. J Dent. 2002;30(1):47-51.

28- Turssi CP, Hara AT, Serra MC, Rodrigues AL Jr. Effect of storage media upon the surface micromorphology of resin-based restorative materials. J Oral Rehabil. 2002;29(9):864-71

29- Wang L, Lopes LG, Bresciani E, Lauris JRP, Mondelli RFL, Navarro MFL. Evaluation of Class I ART restorations in Brazilian schoolchildren: three-year results. Spec Care Dentist. 2004;24(1):28-33

30- Yip HK, Smales RJ, Ngo HC, Tay FR, Chu FCS. Selection of restorative materials for the atraumatic restorative treatment (ART) approach: a review. Spec Care Dentist. 2001;21(6):216-21. 